\title{
Surface Structure Analysis of Initial High-Temperature Oxidation of SS441 Stainless Steel
}

\author{
Tung-Yuan Yung ${ }^{1}$, Hui-Ping Tseng ${ }^{1}$, Wen-Feng Lu ${ }^{1}$, Kun-Chao Tsai ${ }^{1}$, Tien Shen ${ }^{1}$, Hsin-Ming Cheng ${ }^{2, *}(\mathbb{D}$, \\ Jeng-Shiung Chen ${ }^{3}$ and Po-Tuan Chen ${ }^{4, *}$ (i)
}

1 Nuclear Fuels and Materials Division, Institute of Nuclear Energy Research, Taoyuan 325, Taiwan; romeoyung@yahoo.com (T.-Y.Y.); huiping@iner.gov.tw (H.-P.T.); wflu@iner.gov.tw (W.-F.L.); tsaijohn@iner.gov.tw (K.-C.T.); shentien@iner.gov.tw (T.S.)

2 Department of Electronic Engineering and Organic Electronics Research Center, Ming Chi University of Technology, New Taipei City 243, Taiwan

3 Yottadeft Optical-Electron Company, Taipei City 104, Taiwan; jsc@yottadeft.com

4 Department of Vehicle Engineering, National Taipei University of Technology, Taipei 106, Taiwan

* Correspondence: SMCheng@mail.mcut.edu.tw (H.-M.C.); r92222019@ntu.edu.tw (P.-T.C.)

check for updates

Citation: Yung, T.-Y.; Tseng, H.-P.; Lu, W.-F.; Tsai, K.-C.; Shen, T.; Cheng, H.-M.; Chen, J.-S.; Chen, P.-T. Surface Structure Analysis of Initial High-Temperature Oxidation of SS441 Stainless Steel. Materials 2021, 14 , 6136. https://doi.org/10.3390/ ma14206136

Academic Editors: Amir Mostafaei and Mohammadreza Daroonparvar

Received: 29 June 2021

Accepted: 4 October 2021

Published: 15 October 2021

Publisher's Note: MDPI stays neutral with regard to jurisdictional claims in published maps and institutional affiliations.

Copyright: (c) 2021 by the authors. Licensee MDPI, Basel, Switzerland. This article is an open access article distributed under the terms and conditions of the Creative Commons Attribution (CC BY) license (https:/ / creativecommons.org/licenses/by/ $4.0 /)$.

\begin{abstract}
Chromia-forming ferritic stainless steel (FSS) is a highly promising interconnect material for application in solid oxide fuel cells. In this study, initial oxidation of chromium oxides was performed at $500-800{ }^{\circ} \mathrm{C}$ to understand the evolution of materials at an early stage. The structural variations in oxide scales were analyzed through scanning electron microscopy, energy dispersive spectroscopy (EDS), transmission electron microscopy (TEM), X-ray diffractometry (XRD), laser confocal microscopy (LSCM), X-ray photoelectron spectroscopy (XPS), and Raman spectroscopy. Surface electrochemical properties were investigated through electrochemical impedance spectroscopy to understand how the heat treatment temperature affected surface impedance. Treatment temperatures higher than $700{ }^{\circ} \mathrm{C}$ facilitate the diffusion of $\mathrm{Cr}$ and $\mathrm{Mn}$, thus allowing ferritic spinels to form on the surface and leading to high electrical conductivity.
\end{abstract}

Keywords: solid oxide fuel cells; interconnect; high temperature; spinel; oxidation

\section{Introduction}

Among currently available fuel cell types, solid oxide fuel cells (SOFCs) are preferred for stationary power generation and auxiliary power unit applications because they demonstrate high efficiency and fuel flexibility [1-4]. In stacks of SOFCs, individual cells are separated by interconnects, which provide the flow field pattern for the anode and cathode gases and are electrically connected throughout the stack [5]. Ferritic stainless steel (FSS) is the material most frequently chosen for SOFCs because of its impressive machinability, low cost, easy processing and molding, and thermal expansion coefficient similar to other SOFC components [6,7]. However, at high working temperatures $\left(500-800^{\circ} \mathrm{C}\right)$ and after long-term discharge operation, the Fe on the FSS surface forms harmful oxide layers, resulting in increases in resistance, spallation on the material surface, and a decline in fuel cell performance [8-10].

FSS alloys commonly contain $17-24 \mathrm{wt} \%$ chromium (Cr). Prior formation of $\mathrm{Cr}$ oxide layers on the metallic interconnect surface can suppress the Fe oxide generated there and protect the alloys from corrosion [11,12]. Passive Cr oxide layers automatically grow on the surface of FSS, even before SOFC operation, because of the high Cr content in the ambient atmosphere. A moderately thick chromium oxide layer has satisfactory electrical conductivity; thus, the chromium oxide scale must be maintained at below a certain thickness so as to maintain a low electrical resistance over the interconnects $[13,14]$. $\mathrm{Cr}$ oxide of a certain thickness exhibits beneficial long-term oxidation resistance, but $\mathrm{Fe}$ oxides are less protective and grow more rapidly than $\mathrm{Cr}$ oxides. In addition, $\mathrm{Cr}$ oxides 
provide effective adherence to metal substrates and do not spall off with certain coating parameters [15].

Another common problem with SOFCs is that the high flow rate of ambient air on the cathode side causes the evaporation of volatile $\mathrm{Cr}$ species, which reduces the catalytic activity of the cathode [16-18]. Cr evaporation leads to the consumption of $\mathrm{Cr}$ from the steel interconnect. Consequently, $\mathrm{Fe}$ is oxidized rapidly because of the reduced protection by chromium oxides, a process commonly referred to as breakaway oxidation $[19,20]$. Therefore, an appropriate $\mathrm{Cr}$ oxide layer on the surface of FSS can inhibit element volatilization by acting as a diffusion barrier [21].

The corrosion stability of FSS therefore depends on the formation of Cr oxide layers. To form a continuous protective chromium oxide layer, the supply or flux of $\mathrm{Cr}$ from the bulk alloy must compare sufficiently with $\mathrm{Cr}$ consumption through oxidation at the oxide-metal interface [22]. The temperature adjustment during initial $\mathrm{Cr}$ oxidation is a crucial parameter $[23,24]$. Several studies have performed oxidation at temperatures of $800-900^{\circ} \mathrm{C}$ [25]. However, SOFC research is targeting lower operating temperatures to decelerate the degradation of cell components. An operating temperature of approximately $600{ }^{\circ} \mathrm{C}$ is sufficient to maintain satisfactory ionic conductivity of the electrolyte [26]. Although metal oxidation rates are expected to decrease at lower temperatures, several FSS studies have demonstrated that, depending on the atmosphere and alloy composition, the oxidation rate can increase when the temperature is reduced within certain intervals [27-29]. Moreover, Young et al. studied several FSSs at temperatures ranging from $500-900{ }^{\circ} \mathrm{C}$ and revealed that oxidation was generally more severe in the $500-650{ }^{\circ} \mathrm{C}$ region than in the $650-800{ }^{\circ} \mathrm{C}$ region, because more iron oxide nodules formed at the lower temperatures [30]. Goebel et al. reported a dual atmosphere in a pre-oxidation process at $800{ }^{\circ} \mathrm{C}$; the oxide scales contained $\mathrm{Fe}$-rich nodules and a $\mathrm{Cr}$ oxide layer for corrosion resistance [31].

Morphological variations in the short operation time of the initial oxidation have rarely been discussed. However, analyzing the variations of alloys during a short oxidation period can clarify how each element diffuses in an alloy. Moreover, during the initial oxidation stage, the effects of morphological variations are significant.

A commercially available FSS called AISI SS441 was chosen as the test material because it is less expensive than Crofer 22 APU, Crofer 22H, Sanergy HT, and ZMG 232. After the initial protective oxidation, interconnectors have three primary requirements: (i) reliable electrical conductivity; (ii) chemical stability under high-temperature oxidation and in a reducing atmosphere; and (iii) effective oxidation, vulcanization, and carbonization resistance.

Herein, we discuss the microstructural features formed after 10-min oxidation at initial temperatures of $500-800{ }^{\circ} \mathrm{C}$. The morphologies of surface oxide scales and the elemental distributions were investigated through scanning electron microscopy (SEM) and energydispersive spectroscopy (EDS). The nanoscale regions of the oxides were studied through transmission electron microscopy (TEM), XRD, and Raman spectroscopy. Electrochemical impedance spectroscopy (EIS) was used for comparing the chemical impedance of the SS441 pre-oxidized at different initial temperatures and for simulating equivalent circuits.

\section{Experimental Methods}

\subsection{Heat Treatment}

The chemical composition of AISI SS441 is presented in Table 1. SS441 specimens were cut into $10 \times 10-\mathrm{mm}^{2}$ pieces with a thickness of $2 \mathrm{~mm}$, and their surfaces were ground using 1200-grit sandpaper. The specimens were placed exposed in a furnace at 500,600, 700, or $800{ }^{\circ} \mathrm{C}$ for $10 \mathrm{~min}$ and heated at a rate of $5^{\circ} \mathrm{C} / \mathrm{min}$ (Eurotherm 2416 program controller) from room temperature (approximately $27^{\circ} \mathrm{C}$ ), and dried in air at a flow rate of $2 \mathrm{~L} / \mathrm{min}$; thereafter, the samples were cooled at $15^{\circ} \mathrm{C} / \mathrm{min}$ without air flow. 
Table 1. Elemental composition of SS441.

\begin{tabular}{ccccccccc}
\hline Element & $\mathbf{C r}$ & $\mathbf{M n}$ & $\mathbf{N b}$ & $\mathbf{C}$ & $\mathbf{S i}$ & $\mathbf{T i}$ & $\mathbf{S}$ & $\mathbf{F e}$ \\
\hline $\mathrm{Wt} \%$ & 17.7 & 0.30 & 0.37 & 0.015 & 0.55 & 0.15 & 0.002 & Bal. \\
\hline
\end{tabular}

\subsection{Surface Morphology}

After heat treatment, the oxide scales were examined through surface electron microscopy to determine their morphologies, elemental compositions, and phases. A JOEL JEM 7600 surface electron microscope coupled with an Oxford Max energy-dispersive spectroscope without liquid nitrogen cooling, and a JOEL FE2100F transmission electron microscope were used to investigate the electron diffraction patterns of the oxide scales after pretreatment at different temperatures. In this study, the samples were prepared through focused ion beam milling and an in situ lift-out technique using an FEI Versa 3D Dual Beam instrument (FEI Company, Hillsboro, Oregon, OR, USA).

\subsection{Microscale Surface Roughness}

The microscopic surface roughness and cross-sections of the samples were examined using an LEXT OLS 4000 laser confocal microscope (Olympus Corporation, Tokyo, Japan).

\subsection{Oxide Scale Composition and Raman Spectra}

The Oxford Max energy-dispersive spectroscope and a Bruker D8 Discover X-ray diffractometer with $\mathrm{Cu} \mathrm{K} \alpha$ radiation $(\lambda=1.5406 \AA)$ were used to analyze the elemental composition and crystalline phases of the oxide scales at a scanning rate of $4^{\circ} / \mathrm{min}$ over a $2 \theta$ range of $15^{\circ}-80^{\circ}$ with an incident angle of $0.5^{\circ}$. A B\&W Tek iRaman Plus spectrometer was used to analyze all samples with a 785-nm laser and a 600-mm slit width. X-ray photoelectron spectroscopy (XPS) was performed on a Thermo VG ESCALAB 250 equipped with a dual anode $(\mathrm{Mg} \mathrm{Ka} / \mathrm{Al} \mathrm{Ka}) \mathrm{X}$-ray source.

\subsection{Surface Impedance}

An Autolab PASTAT 30 (AUTOLAB, Utrecht, Netherlands) was used to examine the oxide scales in a three-electrode cell with a Pt wire as the counter electrode, $\mathrm{Ag} / \mathrm{AgCl}$ as the reference electrode, and the heat-treated specimens welded to a $\mathrm{Pt}$ wire as the working electrode. The electrolyte was $0.1 \mathrm{M} \mathrm{NaCl}$ (aqueous) at room temperature. EIS was performed with an open-circuit potential amplitude of $10 \mathrm{mV}$. EIS equivalent circuit analysis was performed on Zview. EIS is a powerful method for quantifying the three parameters defining a corrosion process: (i) the corrosion rate, through the charge transfer resistance $\left(\mathrm{R}_{\mathrm{ct}}\right)\left(\mathrm{W} \mathrm{cm}{ }^{2}\right)$ and using Faraday's law to estimate the penetration of the attack ( $\mu \mathrm{m} /$ day); (ii) diffusion processes defined by the parameter Warburg $\left(\mathrm{W} \mathrm{cm}^{2} / \mathrm{s}^{1 / 2}\right)$; and (iii) electrochemical double-layer capacitance at the metal-solution interface $\left(\mathrm{C}_{\mathrm{dl}}\right)\left(\mathrm{F} / \mathrm{cm}^{2}\right)$.

\section{Results}

\subsection{Oxide Scale Morphology and Elemental Analysis}

Figure 1 presents the surface morphology of the oxide scales after heat treatment at $500,600,700$, and $800{ }^{\circ} \mathrm{C}$. The $\mathrm{Fe}, \mathrm{Cr}, \mathrm{O}$, and $\mathrm{Nb}$ oxides glowed up as the temperature increased. The particle-like oxides were noted in the tool scratch line. The surface defects also enhanced oxidation at higher temperatures.

The elemental compositions were analyzed through energy dispersive spectroscopy (EDS), and the results are listed in Table 2. The $\mathrm{Cr}$ content was the highest at $800{ }^{\circ} \mathrm{C}$ $(17.41 \%)$ and the lowest at $700{ }^{\circ} \mathrm{C}(14.72 \%)$. As shown in Table 1, the $\mathrm{Cr}$ content in the specimen as received was $17.70 \%$. Cr evaporation pressure was lower than that of $\mathrm{Fe}, \mathrm{Mn}$, and $\mathrm{Nb}$. Chromium oxide formed the protection layer on the FSSs. Nevertheless, the Fe and $\mathrm{Nb}$ contents were the same as $\mathrm{Cr}$ after accounting for differences in heat treatments. Furthermore, it was revealed that the oxygen content in the oxide scale compositions increased with increasing heat-treatment temperatures. At $800{ }^{\circ} \mathrm{C}$, the oxides were spread 
more widely than at other temperatures. However, manganese was not detected through EDS for specimens treated at temperatures below $800^{\circ} \mathrm{C}$.
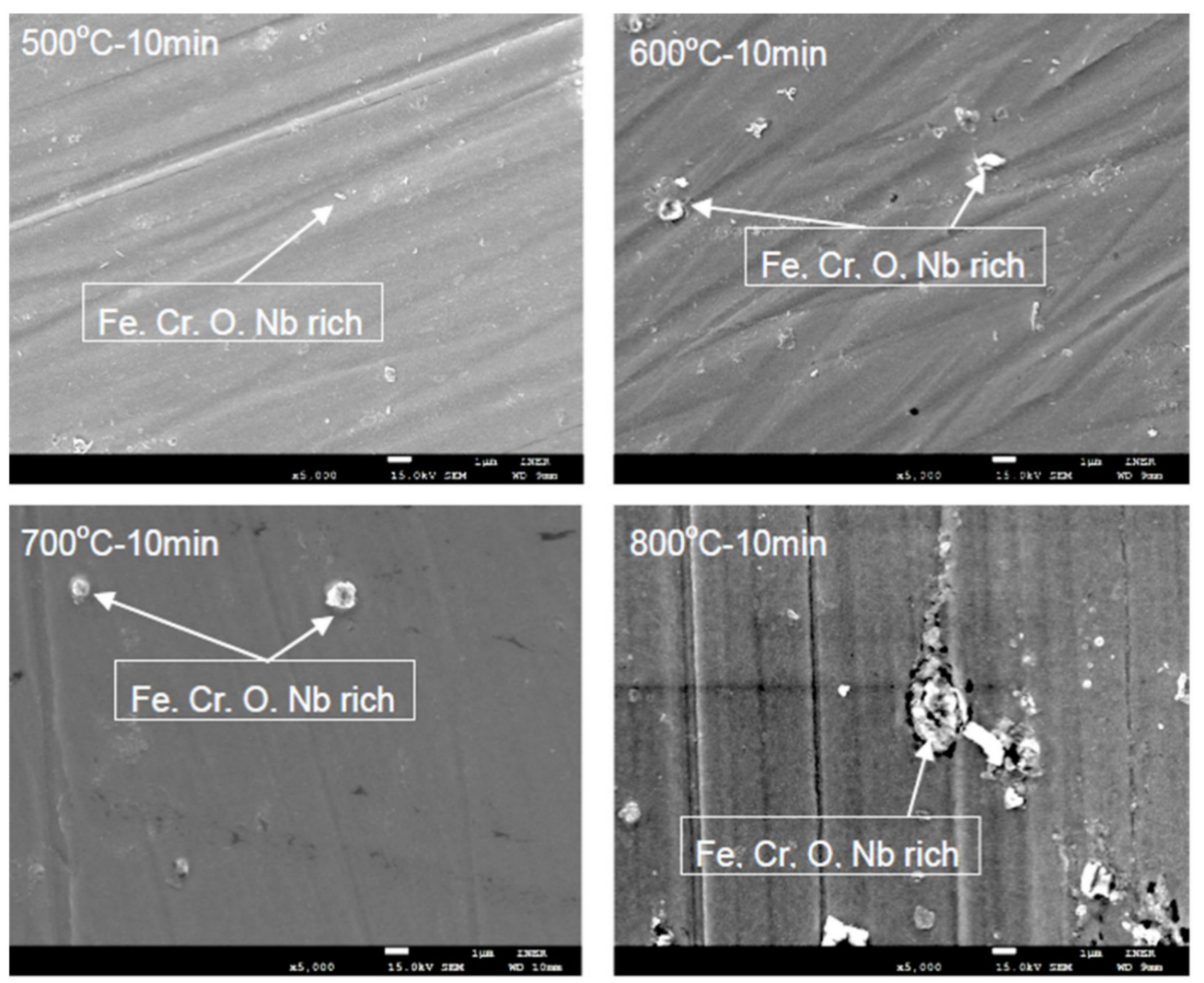

Figure 1. Surface morphology after treatment at $500,600,700$, and $800^{\circ} \mathrm{C}$ for $10 \min$ (scale bar: $1 \mu \mathrm{m}$ ).

Table 2. Elemental composition determined through EDS.

\begin{tabular}{ccccc}
\hline Atomic $\mathbf{\%}$ & $\mathbf{5 0 0}{ }^{\circ} \mathbf{C}-\mathbf{1 0} \mathbf{~}$ in & $\mathbf{6 0 0}{ }^{\circ} \mathbf{C}-\mathbf{1 0} \mathbf{~ m i n}$ & $\mathbf{7 0 0}{ }^{\circ} \mathbf{C}-\mathbf{1 0} \mathbf{~ m i n}$ & $\mathbf{8 0 0}{ }^{\circ} \mathbf{C - 1 0} \mathbf{~ m i n}$ \\
\hline $\mathrm{Fe}$ & 63.99 & 63.69 & 62.85 & 69.10 \\
$\mathrm{Cr}$ & 16.01 & 15.92 & 14.7 & 17.41 \\
$\mathrm{Nb}$ & 0.39 & 0.27 & 0.23 & 0.39 \\
$\mathrm{Mn}$ & - & - & 0.40 & 0.45 \\
$\mathrm{O}$ & 5.71 & 6.34 & 7.7 & 11.46 \\
\hline
\end{tabular}

Laser confocal microscopy with z-axis autofocusing revealed the surface roughness of the SS441 samples after heat treatment at various temperatures. The surface roughness was $20.35 \pm 4.23,30.55 \pm 7.88,37.27 \pm 7.88$, and $47.54 \pm 9.87 \mathrm{~nm}$ for the treatment temperatures of $500,600,700$, and $800{ }^{\circ} \mathrm{C}$, respectively.

Cross-sectional images of the heat-treated SS441 specimens are displayed in Figure 2. The oxide scale surface revealed increasing curvatures at higher heat-treatment temperatures, coherent with the surface roughness profiles. When the energy input was increased, the elements increasingly evaporated at higher temperatures. Thus, the surface roughness and curvature were observable in the cross-sectional images.

The oxide scale cross-sectional thicknesses were calculated with the JOEL JEM 7600 and are presented in Figure 3. The thickness differences decreased with increasing heattreatment temperatures. The approximate thickness differences were 13.2, 12.0, and $3.1 \mathrm{~nm}$ at 500-600, 600-700, and $700-800{ }^{\circ} \mathrm{C}$, respectively. Thus, oxide scale propagation was most favorable in the region of $500-700{ }^{\circ} \mathrm{C}$. Additionally, the oxide scale surface roughness increased with the pre-oxidation temperature. Elemental diffusion from the substrate was stronger at $800{ }^{\circ} \mathrm{C}$ because a $\mathrm{Cr}$ oxide scale had formed. 

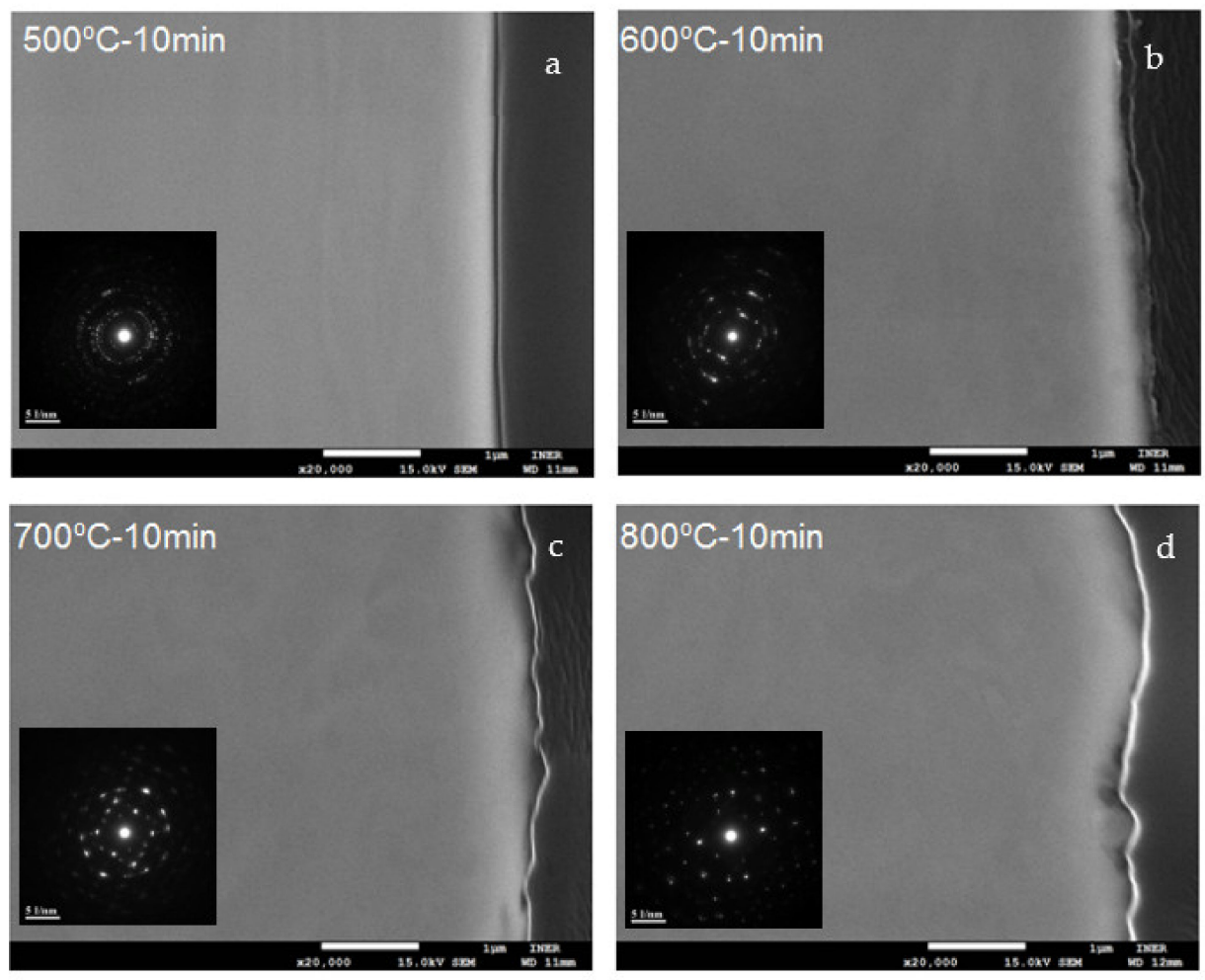

Figure 2. Cross-sectional SEM and TEM images of samples treated at (a) 500, (b) 600, (c) 700, and (d) $800{ }^{\circ} \mathrm{C}$ for $10 \mathrm{~min}$ (scale bar: $1 \mu \mathrm{m}$ ). The insets in the bottom left are the selected area diffraction patterns, with scale bars of $0.05 \mathrm{~nm}$.

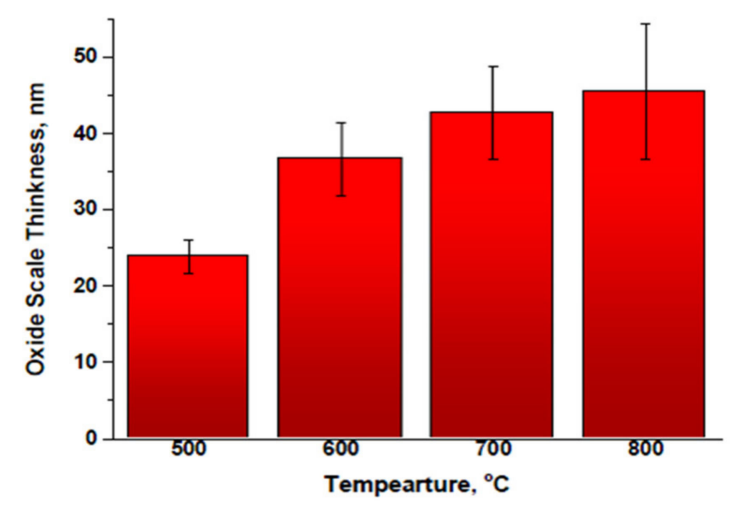

Figure 3. Oxide scale thicknesses as determined from cross-sectional SEM images.

The cross-sectional images in Figure 2 display the oxide scales, which exhibit the second $\mathrm{Cr}$ oxide layer, or spinel structures, on the top of the surface. However, identification of the specific crystalline phase was difficult. Clear ring patterns formed at temperatures of $500-700{ }^{\circ} \mathrm{C}$. The oxide scale formed at $800{ }^{\circ} \mathrm{C}$ revealed only a partial ring pattern. The $\mathrm{Cr}$ oxide scales transitioned into a spinel crystal structure, as determined through the SAED analysis method for SS441 with the pre-oxidation at $800{ }^{\circ} \mathrm{C}$ for $10 \mathrm{~min}$. At heat treatment temperatures of 500 and $600{ }^{\circ} \mathrm{C}$, the electron diffraction ring patterns indicated the rearrangement of the crystal structures of the oxides.

Furthermore, at higher temperatures, the surface roughness was altered by the spinel crystal formation. The low-melting-point elements possibly evaporated because of the higher kinetic energy produced by the higher temperatures. The oxide scales were investigated through TEM, and the results are shown in Figure 3. Each bar was 25 measurements on average, with the error $\pm 0.7 \mathrm{~nm}, \pm 1.6 \mathrm{~nm}, \pm 2.1 \mathrm{~nm}$, and $\pm 3.4 \mathrm{~nm}$ for $500{ }^{\circ} \mathrm{C}, 600{ }^{\circ} \mathrm{C}$, $700{ }^{\circ} \mathrm{C}$, and $800{ }^{\circ} \mathrm{C}$, respectively. 


\subsection{Oxide Scale Crystalline Size and Chemical Environment}

Oxide scale propagation after heat treatment was notable with regard to the crystalline phase. XRD revealed the crystalline phases of the oxide scales, which the X-ray penetrated only to approximately $10 \mu \mathrm{m}$ of depth. The XRD results are presented in Figure 4 . The interconnect alloy contained a considerable amount of $\mathrm{Cr}$ and formed $\mathrm{Cr}_{2} \mathrm{O}_{3}$ scales to provide protection under the elevated temperatures. Mn was added to limit $\mathrm{Cr}$ diffusion and to lower the electrical contact resistance. Si was added for the suppression of the inverse effect of $\mathrm{Nb}$ in oxidation. Laves phase are formed in the substrate after heat treatment for FSS.

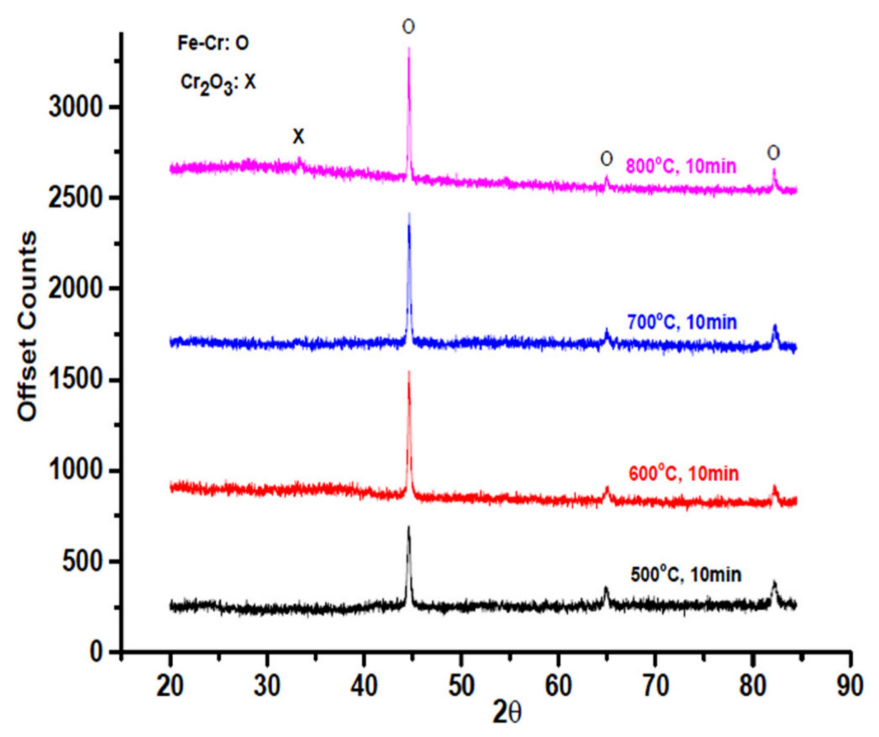

Figure 4. Oxide scale thicknesses as revealed in cross-sectional analysis through transmission electron microscopy.

A $2 \theta \mathrm{Cr}$ oxide peak was observed at $33.1^{\circ}$ for the sample treated at $800^{\circ} \mathrm{C}$. The $2 \theta \mathrm{Fe}-\mathrm{Cr}$ peaks were at approximately $44^{\circ}, 64.8^{\circ}$, and $82.5^{\circ}$. The spinel species in oxidized FSSs have received much attention, particularly when developed through the thermal conversion approach, due to their effectiveness in suppressing the growth of chromium oxide layers and reducing outward migration of $\mathrm{Cr}[32,33]$. A grazing-incidence XRD (GIXRD) angle of $1^{\circ}$ was used for the thin oxide scales. However, the $2 \theta$ peaks at approximately $64.8^{\circ}$ and $82.5^{\circ}$ disappeared in the GIXRD analysis. The peaks at approximately $44^{\circ}$ indicated the preferred orientation of the SS441 Fe-Cr structure. The substrate crystalline structure still dominated the diffraction peaks as the preferred orientation. However, different heat treatment temperatures and times can affect the crystalline size and orientation. The Scherrer equation for the peak width of the half peak high, revealing crystalline size, is as follows:

$$
\tau=\kappa \lambda / F W H M \cos \theta
$$

where $\tau$ is the crystalline size, $\mathrm{K}$ is a dimensionless shape factor with a value close to unity, $\lambda$ is the X-ray wavelength, FWHM is the full width at half maximum, and $\theta$ is found in the $\mathrm{x}$-axis.

The SS441 substrate may have contributed to the peak intensities shown in Figure 4, but the full width at half maximum changed with the temperature. As the temperature rises, the $\mathrm{Cr}$ diffusion rate increases. The $\mathrm{Fr}-\mathrm{Cr}$ peaks for the pre-oxidation process indicated that the surface oxide structure served as a precursor for the spinel structure $(\mathrm{Fe}, \mathrm{Cr}, \mathrm{Mn})_{3} \mathrm{O}_{4}$.

As shown in Table 3, the crystalline size increased with increasing temperature. The spinel crystalline sizes were $31.80,39.84,41.71$, and $47.79 \mathrm{~nm}$ at $500,600,700$, and $800{ }^{\circ} \mathrm{C}$, respectively. The initial oxidation required a short time at the various temperatures. Furthermore, the peak ratios indicated the presence of crystalline structures. 
Table 3. XRD peak analysis with Scherrer's equation.

\begin{tabular}{cccc}
\hline Entry & Peak Position (2 $\theta)$ & FWHM & Size (nm) \\
\hline $500^{\circ} \mathrm{C}-10 \mathrm{~min}$ & $44.65^{\circ}$ & $0.3324^{\circ}$ & 25.12 \\
$600^{\circ} \mathrm{C}-10 \mathrm{~min}$ & $44.61^{\circ}$ & $0.3601^{\circ}$ & 31.80 \\
$700^{\circ} \mathrm{C}-10 \mathrm{~min}$ & $44.65^{\circ}$ & $0.2951^{\circ}$ & 39.84 \\
$800^{\circ} \mathrm{C}-10 \mathrm{~min}$ & $44.65^{\circ}$ & $0.2827^{\circ}$ & 41.71 \\
\hline
\end{tabular}

The Bruker EVA software program uses a semi-quantitative method for analyzing the crystalline composition; the results of the analysis are presented in Table 4 . At $600{ }^{\circ} \mathrm{C}$, the $\alpha$-Fe crystalline content was the lowest $(9.2 \%)$, and the $\mathrm{Fe}-\mathrm{Cr}$ crystalline was the highest $(69.3 \%)$. Spinel crystallization occurred at approximately $600{ }^{\circ} \mathrm{C}$. Treatments at higher temperatures revealed no considerable differences in their crystal structures. For long-term SOFC application, an operational temperature below $600{ }^{\circ} \mathrm{C}$ should thus be considered.

Table 4. Crystalline compositions of SS441 surfaces using the semiquantitative method and Bruker EVA XRD analysis software.

\begin{tabular}{cccc}
\hline & Fe & Fe-Cr & Fe $_{\mathbf{1 9}} \mathbf{M n}$ \\
\hline $500{ }^{\circ} \mathrm{C}, 10 \mathrm{~min}$ & $48.4 \%$ & $39.0 \%$ & $12.5 \%$ \\
$600{ }^{\circ} \mathrm{C}, 10 \mathrm{~min}$ & $9.2 \%$ & $69.3 \%$ & $21.5 \%$ \\
$700^{\circ} \mathrm{C}, 10 \mathrm{~min}$ & $15.8 \%$ & $62.9 \%$ & $21.3 \%$ \\
$800{ }^{\circ} \mathrm{C}, 10 \mathrm{~min}$ & $16.6 \%$ & $60.1 \%$ & $23.3 \%$ \\
\hline
\end{tabular}

The oxide scale chemical environment was investigated through XPS. The $\mathrm{Cr} 2 \mathrm{p}$ and Mn $2 p$ are presented in Figure 5. The highest $\mathrm{Cr} 2 \mathrm{p}$ and Mn $2 \mathrm{p}$ peak intensities were at 700 and $800{ }^{\circ} \mathrm{C}$, respectively. The highest $\mathrm{Cr}$ and $\mathrm{Mn}$ diffusion rates were observed at 700 and $800{ }^{\circ} \mathrm{C}$, respectively. However, no notable peaks appeared at $600{ }^{\circ} \mathrm{C}$. The cross-sectional SEM/EDS data in Table 2 reveal Mn content of $0.4 \mathrm{wt} \%$ for pre-oxidation at $700{ }^{\circ} \mathrm{C}-10 \mathrm{~min}$. The Mn $2 \mathrm{p}$ peak was apparent after heat treatment at $700{ }^{\circ} \mathrm{C}$. Heat treatment for $1 \mathrm{~h}$ at $700{ }^{\circ} \mathrm{C}$ resulted in a decrease in the $\mathrm{Cr} 2 \mathrm{p}$ peak intensity but an increase in the Mn $2 \mathrm{p}$ peak intensity. Thus, $700{ }^{\circ} \mathrm{C}$ is the critical temperature for the $\mathrm{Cr} / \mathrm{Mn}$ ratio of the oxide scales. Using a curve fitting analysis for the $\mathrm{Cr} 2 \mathrm{p}$ and $\mathrm{Mn} 2 \mathrm{p}$ spectra, the ratios of $\mathrm{CrO}_{2} / \mathrm{CrO}_{3}$ were found to be $2 / 11,50 / 19,2 / 7$, and $25 / 6$ at $500,600,700$, and $800{ }^{\circ} \mathrm{C}$, respectively. Before using metallic interconnects for SOFC, the aforementioned factors should be considered. The higher the Mn content, the greater the electrical conductivity. Spinel minerals belong to a large group of compounds with cubic symmetry (space group Fd3m, Hermann-Mauguin notation $\mathrm{Oh}$ ); the general chemical formula $\mathrm{AB}_{2} \mathrm{X}_{4}$, where $\mathrm{A}$ and $\mathrm{B}$ are cations with variable valences and $\mathrm{X}$ is an anion, which can be $\mathrm{O}_{2}{ }^{-}, \mathrm{S}_{2}{ }^{-}, \mathrm{Se}_{2}{ }^{-}$, or $\mathrm{Te}_{2}{ }^{-}[34,35]$.
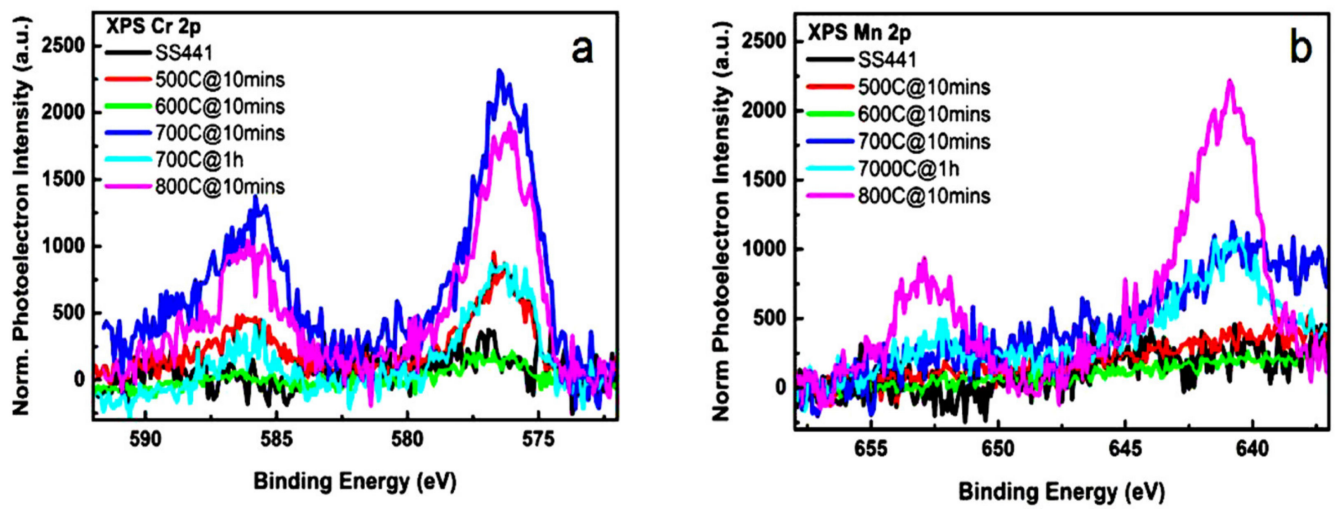

Figure 5. XPS results for oxide scales of specimens pre-oxidized at 500,600, 700, and $800{ }^{\circ} \mathrm{C}$. (a) $\mathrm{Cr}$ 2p (b) Mn 2p. 
Raman spectroscopy is widely used for the routine identification of materials and has highly promising applications in spinel materials. It may aid in distinguishing spinel species from characteristic spectral patterns ("fingerprints") without preliminary information about the composition and structural origin of individual features. D'lppolito et al. reported the Raman spectra of chromate, aluminate, and ferrite spinels in 2015 [35]. The ferrite spinels they used for Raman analysis were $\mathrm{FeFe}_{2} \mathrm{O}_{4}$ and $\mathrm{FeCr}_{2} \mathrm{O}_{4}$. The authors revealed four peaks for $\mathrm{F}_{2} \mathrm{~g}(1), \mathrm{Eg}, \mathrm{F}_{2} \mathrm{~g}(2)$, and $\mathrm{F}_{2} \mathrm{~g}(3)$. The $\mathrm{FeFe}_{2} \mathrm{O}_{4}$ spinel was revealed by the $A_{1} g$ vibrational mode at approximately $675 \mathrm{~cm}^{-1}$. They also reported three peaks for the $\mathrm{MnAl}_{2} \mathrm{O}_{3}$ spinel at 200, 400, and $520 \mathrm{~cm}^{-1}$ for $\mathrm{F}_{2} \mathrm{~g}(1), \mathrm{Eg}$, and $\mathrm{F}_{2} \mathrm{~g}(2)$, respectively. The $\mathrm{F}_{2} \mathrm{~g}(2)$ peak of $\mathrm{MnAl}_{2} \mathrm{O}_{4}$ and $\mathrm{A}_{1} \mathrm{~g}$ peak of $\mathrm{FeFe}_{2} \mathrm{O}_{4}$ are visible in the Raman spectra at $600-750 \mathrm{~cm}^{-1}$. The laser wavelength for the Raman analysis was $785 \mathrm{~nm}$; in Figure 6, the red and green spectra reveal that heat treatment below $700{ }^{\circ} \mathrm{C}$ did not exhibit the $\mathrm{Eg}$, $\mathrm{F}_{2} \mathrm{~g}(2)$, and $\mathrm{F}_{2} \mathrm{~g}(3)$ peaks at 418,531 , and $681 \mathrm{~cm}^{-1}$, respectively. A1g shoulder peaks were observed at a wavenumber of $623 \mathrm{~cm}^{-1}$. These A1g peaks appeared with temperatures above $600{ }^{\circ} \mathrm{C}$. The three Raman-active F2g modes are labeled as F2g(1), F2g(2), and F2g(3), with F2g(1) being associated with the lowest Raman shift and F2g(3) indicating the Raman F2g symmetry mode at the highest wavenumber. However, above $600{ }^{\circ} \mathrm{C}$, the F2g(3) peaks for the SS441 specimens included shoulder peaks at approximately $623 \mathrm{~cm}^{-1}$, indicating the presence of a ferritic spinel structure with $\mathrm{Mn}, \mathrm{Fe}(\mathrm{Cr}, \mathrm{Mn})_{2} \mathrm{O}_{4}$. Moreover, the $\mathrm{F}_{2} \mathrm{~g}(3) / \mathrm{A}_{1} \mathrm{~g}$ ratio was approximately 3 , effectively the same as the $\mathrm{Fe}-\mathrm{Cr} / \mathrm{Fe}_{19} \mathrm{Mn}$ ratio in Table 4.

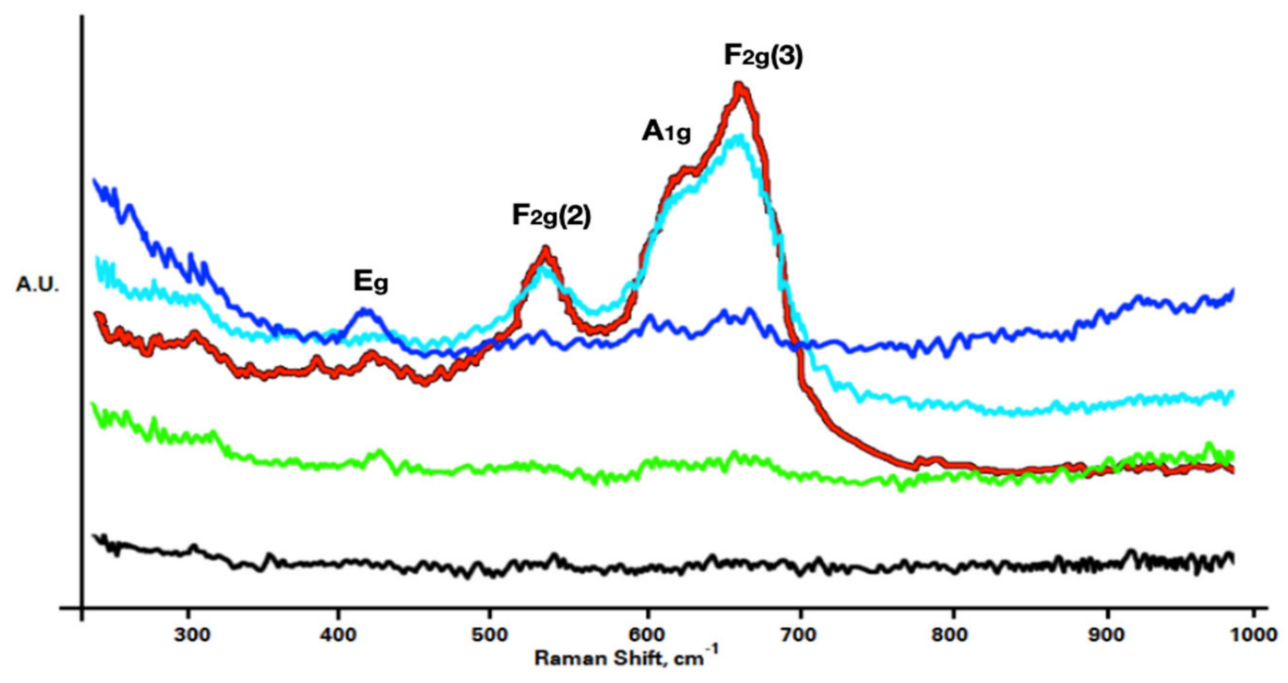

Figure 6. Raman spectra at $785 \mathrm{~nm}$ revealing vibrational modes for oxide scales. The black, green, blue, light blue, and red indicate the as-received, 500, 600, 700, and $800^{\circ} \mathrm{C}$ samples, respectively.

\subsection{Electrochemical Properties of Oxide Scales}

After heat treatment at various temperatures for $10 \mathrm{~min}$, the electrochemical properties of the oxide scales were analyzed. The EIS equivalent circuit was analyzed using Zview software; the results revealed that increasing heat-treatment temperatures directly increased electrochemical impedance. The EIS equivalent circuit fitting results are presented in Figure 7 and Table 5. The EIS equivalent circuit fitting scheme is displayed in Figure 7.

Two equivalent circuits were employed for SS41 heat treatments at $\geq 600{ }^{\circ} \mathrm{C}$. One was $R(Q R)(Q R)$, and the other was $R(Q R)(Q R)(Q R)$; here, $R$ is electrolyte resistance, and $(\mathrm{QR})$ is the electrical resistance and constant phase element (CPE) of the oxide layer on the SS441 surface. Moreover, $\mathrm{R}$ is defined by the electrical resistance of charge transfer. The trend increases with increasing temperature. CPE could be the capacity between the different oxide layers. The third (QR) noted after heat treatment at $700{ }^{\circ} \mathrm{C}$ indicated the highest resistance. 


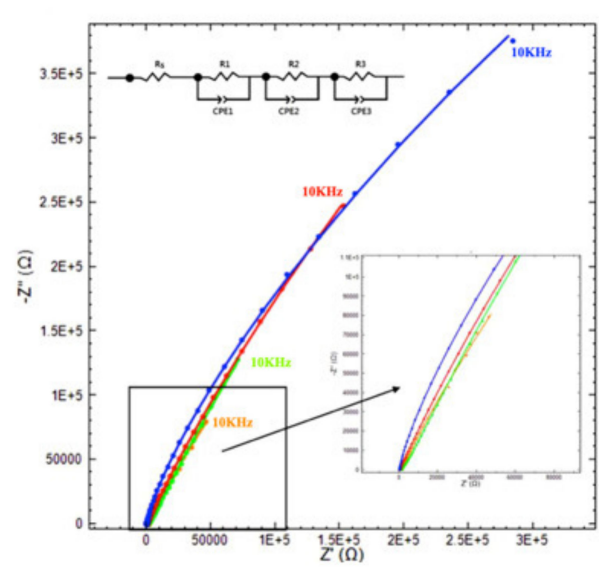

(a)

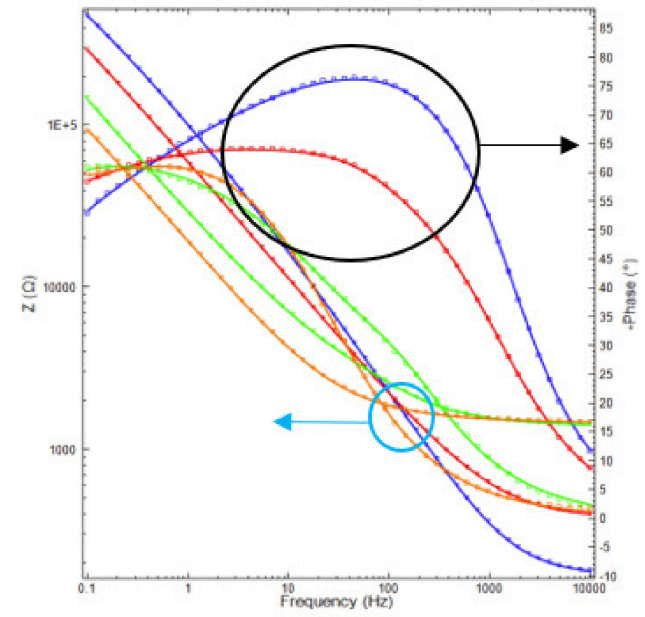

(b)

Figure 7. Nyquist (a) and Bode (b) and plots for heat treatments at $500{ }^{\circ} \mathrm{C}, 600{ }^{\circ} \mathrm{C}, 700{ }^{\circ} \mathrm{C}$, and $800{ }^{\circ} \mathrm{C}$ with blue, red, green and orange, respectively. The dots are EIS data, and the line is the simulated equivalent circuit.

Table 5. Results of equivalent circuit simulation.

\begin{tabular}{cccccccc}
\hline & $\begin{array}{c}\text { Rs } \\
(\mathbf{k} \Omega)\end{array}$ & $\begin{array}{c}\mathbf{R} 1 \\
(\mathbf{k} \Omega)\end{array}$ & $\begin{array}{c}\text { Capacitor } \\
(\mathbf{m F})\end{array}$ & $\begin{array}{c}\mathbf{R} 2 \\
(\mathbf{M} \Omega)\end{array}$ & $\begin{array}{c}\mathbf{C P E} 1 / \mathbf{n} \\
(\boldsymbol{\mu} \mathbf{M h o})\end{array}$ & $\begin{array}{c}\mathbf{R} 3 \\
(\mathbf{k} \boldsymbol{\Omega})\end{array}$ & $\begin{array}{c}\mathbf{C P E} / \mathbf{n} \\
(\boldsymbol{\mu} \mathbf{M h o})\end{array}$ \\
\hline $500^{\circ} \mathrm{C}-10 \mathrm{~min}$ & 0.17 & 4.58 & 0.794 & 2.96 & $2.25 / 0.581$ & - & - \\
$600^{\circ} \mathrm{C}-10 \mathrm{~min}$ & 0.37 & 9.18 & 1.01 & 4.56 & $3.83 / 0.636$ & 1.26 & $8.02 / 0.703$ \\
$700^{\circ} \mathrm{C}-10 \mathrm{~min}$ & 1.39 & 1.02 & 2.23 & 0.73 & $14.8 / 0.784$ & 2.36 & $21.9 / 0.589$ \\
$800^{\circ} \mathrm{C}-10 \mathrm{~min}$ & 1.46 & 2.51 & 4.45 & 1.10 & $11.3 / 0.589$ & 2.05 & $76.6 / 0.526$ \\
\hline
\end{tabular}

The Nyquist plots for $10 \mathrm{kHz}$ from the highest resistance to the lowest resistance are shown on the right side of Figure 7. The phase angles and real resistances in Bode plot show a decline in the response frequency of the resistance turning point as the phase angle shifted with the heat treatment temperature from 500 to $800^{\circ} \mathrm{C}$, as also shown on the right side of Figure 7. The ratio of $\mathrm{Fe}-\mathrm{Cr}$ to $\mathrm{Fe}_{19} \mathrm{Mn}$ (Table 4) determined through semiquantitative XRD decreased as the treatment temperature increased, meaning the $\mathrm{Mn}$ element diffused more from the substrate to the surface.

In our previous study on the pre-oxidation of SS441 for $25 \mathrm{~h}$, the surface spinel structure $(\mathrm{Mn}, \mathrm{Cr})_{3} \mathrm{O}_{4}$ was observed from a top view and through cross-sectional SEM/EDS analysis [36]. Nevertheless, the 10-min pre-oxidation of SS441 did not produce $(\mathrm{Mn}, \mathrm{Cr})_{3} \mathrm{O}_{4}$, but did produce $(\mathrm{Fe}, \mathrm{Cr}, \mathrm{Mn})_{3} \mathrm{O}_{4}$ instead. The Rs value and oxide scale thickness increased with the heat treatment temperature, as shown in Table 5.

$\mathrm{R} 1, \mathrm{R} 2$, and R3 are defined respectively as the electron-metal resistance, the oxide-oxide resistance, and the oxide-substrate resistance. The values of $\mathrm{R} 1$ for the samples preoxidized at 700 and $800{ }^{\circ} \mathrm{C}$ were 1.02 and $2.51 \mathrm{k} \Omega$, respectively. The highest values for $\mathrm{R} 2$ and $\mathrm{R} 3$ were for the sample treated at $600{ }^{\circ} \mathrm{C}$. The capacitance also rose with the pre-oxidation temperature. The Mn diffusion from the substrate to the surface enhanced the electrical conductivity of the oxide scales and enabled the electron double-layer to serve as a capacitor. The XPS spectra in Figure 5 reveal that the Mn diffused at pre-oxidation temperatures above $600{ }^{\circ} \mathrm{C}$. The SEM/EDS results also revealed Mn diffusion from the substrate to the surface for temperatures above $600{ }^{\circ} \mathrm{C}$. Thus, the Mn content in the oxide scale enhanced the electrical conductivity after pre-oxidation of SS441 at such temperatures.

\section{Conclusions}

The pre-oxidation of SS441 interconnects for SOFC can improve fuel cell performance by enhancing electrical properties. The structural variations and electrochemical behavior of interconnects with initial oxidation at different temperatures has been analyzed sys- 
tematically. The experiments in the present study revealed that heat treatment of FSS at approximately $700{ }^{\circ} \mathrm{C}$, at which $\mathrm{Cr}$ oxides transition into $(\mathrm{Fe}, \mathrm{Cr}, \mathrm{Mn})_{3} \mathrm{O}_{4}$, enhanced electrical conductivity. As revealed by the XRD and Raman spectra, the oxide scales were ferritic spinel $(\mathrm{Fe}, \mathrm{Cr}, \mathrm{Mn})_{3} \mathrm{O}_{4}$. The $\mathrm{Cr}$ and $\mathrm{Mn}$ content in the oxide scales after heat treatment increased with the treatment temperature. In EDS, XRD, XPS, Raman, and EIS analysis, Mn content was found in the oxide scales of only those samples treated at temperatures above $700{ }^{\circ} \mathrm{C}$. EIS revealed the presence of three (QR) layers in the treated samples. The temperature of $600{ }^{\circ} \mathrm{C}$ for 10 -min pre-oxidation is the threshold for Mn evaporation. A combination of a pre-oxidation process and a protective coating layer should be investigated in the future.

Author Contributions: Conceptualization, T.-Y.Y., H.-M.C. and P.-T.C.; methodology, H.-P.T., W.-F.L., K.-C.T. and T.S.; validation, T.-Y.Y., H.-M.C. and P.-T.C.; investigation resources, T.-Y.Y., H.-M.C. and P.-T.C.; data curation, J.-S.C.; writing-original draft preparation, T.-Y.Y.; writing-review and editing, T.-Y.Y.; visualization, J.-S.C.; supervision, T.-Y.Y.; funding acquisition, T.-Y.Y., H.-M.C. and P.-T.C. All authors have read and agreed to the published version of the manuscript.

Funding: This study was supported financially by the Ministry of Science and Technology of Taiwan, R.O.C. (108-2113-M-027 -008 -MY2 and 109-2112-M-131-001).

Institutional Review Board Statement: Not applicable.

Informed Consent Statement: Not applicable.

Data Availability Statement: Data sharing is not applicable for this article.

Acknowledgments: The authors thank the Computer and Information Network Center at the National Taiwan University for providing calculation resources.

Conflicts of Interest: The authors declare that they have no competing financial interests.

\section{References}

1. Sazali, N. Emerging Technologies by Hydrogen: A Review. Int. J. Hydrog. Energy 2012, 45, 18753-18771. [CrossRef]

2. Baratto, F.; Diwekar, U.M. Life Cycle Assessment of Fuel Cell-Based APUs. J. Power Sources 2005, 139, 188-196. [CrossRef]

3. Fernandes, M.; Andrade, S.T.D.P.; Bistritzki, V.; Fonseca, R.M.; Zacarias, L.; Gonçalves, H.; de Castro, A.; Domingues, R.; Matencio, T. SOFC-APU Systems for Aircraft: A Review. Int. J. Hydrog. Energy 2018, 43, 16311-16333. [CrossRef]

4. Staffell, I.; Ingram, A.; Kendall, K. Energy and Carbon Payback Times for Solid Oxide Fuel Cell Based Domestic CHP. Int. J. Hydrog. Energy 2012, 37, 2509-2523. [CrossRef]

5. Minh, N. Solid Oxide Fuel Cell Technology—Features and Applications. Solid State Ionics 2004, 174, 271-277. [CrossRef]

6. Kendall, K. Progress in Solid Oxide Fuel Cell Materials. Int. Mater. Rev. 2013, 50, 257-264. [CrossRef]

7. Mahato, N.; Banerjee, A.; Gupta, A.; Omar, S.; Balani, K. Progress in Material Selection for Solid Oxide Fuel Cell Technology: A Review. Prog. Mater. Sci. 2015, 72, 141-337. [CrossRef]

8. Grolig, J.G.; Froitzheim, J.; Svensson, J.E. Coated Stainless Steel 441 as Interconnect Material for Solid Oxide Fuel Cells: Oxidation Performance and Chromium Evaporation. J. Power Sources 2014, 248, 1007-1013. [CrossRef]

9. Saunders, S.R.J.; Monteiro, M.; Rizzo, F. The Oxidation Behavior of Metals and Alloys at High Temperatures in Atmospheres Containing Water Vapour: A Review. Prog. Mater. Sci. 2008, 53, 775-837. [CrossRef]

10. Mah, J.C.; Muchtar, A.; Somalu, M.R.; Ghazali, M.J. Metallic Interconnects for Solid Oxide Fuel Cell: A Review on Protective Coating and Deposition Techniques. Int. J. Hydrog. Energy 2017, 42, 9219-9229. [CrossRef]

11. Talic, B.; Molin, S.; Hendriksen, P.V.; Lein, H.L. Effect of Pre-oxidation on the Oxidation Resistance of Crofer 22 APU. Corros. Sci. 2018, 138, 189-199. [CrossRef]

12. Barelli, L.; Barluzzi, E.; Bidini, G. Diagnosis Methodology and Technique for Solid Oxide Fuel Cells: A Review. Int. J. Hydrog. Energy 2013, 38, 5060-5074. [CrossRef]

13. Gazzarri, J.; Kesler, O. Short-stack modeling of degradation in solid oxide fuel cells: Part, I. Contact degradation. J. Power Sources 2008, 176, 138-154. [CrossRef]

14. Alnegren, P.; Sattari, M.; Svensson, J.-E.; Froitzheim, J. Temperature Dependence of Corrosion of Ferritic Stainless Steel in Dual Atmosphere at $600-800{ }^{\circ} \mathrm{C}$. J. Power Sources 2018, 392, 129-138. [CrossRef]

15. Yang, Z.; Guo, M.; Wang, N.; Ma, C.; Wang, J.; Han, M. A Short Review of Cathode Poisoning and Corrosion in Solid Oxide Fuel Cell. Int. J. Hydrog. Energy 2017, 42, 24948-24959. [CrossRef]

16. Jiang, S.P.; Chen, X. Chromium Deposition and Poisoning of Cathodes of Solid Oxide Fuel Cells: A Review. Int. J. Hydrog. Energy 2014, 39, 505-531. [CrossRef] 
17. Key, C.; Eziashi, J.; Froitzheim, J.; Amendola, R.; Smith, R.; Gannon, P. Methods to Quantify Reactive Chromium Vaporization from Solid Oxide Fuel Cell Interconnects. J. Electrochem. Soc. 2014, 161, C373-C381. [CrossRef]

18. Sachitanand, R.; Svensson, J.-E.; Froitzheim, J. The Influence of Cr Evaporation on Long Term Cr Depletion Rates in Ferritic Stainless Steels. Oxid. Met. 2015, 84, 241-257. [CrossRef]

19. Chen, Z.; Wang, L.-J.; Li, F.-S.; Chou, K.-C. Oxidation Mechanism of Fe-16Cr alloy as SOFC Interconnect in Dry/Wet Air. J. Alloy. Compd. 2013, 574, 437-442. [CrossRef]

20. Magdefrau, N.; Chen, L.; Anidow, M. Effects of Alloy Heat Treatment on Oxidation Kinetics and Scale Morphology for Crofer 22 APU. J. Power Sources 2013, 241, 756-767. [CrossRef]

21. Kofstad, P. High Temperature Corrosion; Elsevier Applied Science Publishers Ltd.: New York, NY, USA, 1988.

22. Falk-Windisch, H.; Svensson, J.E.; Froitzheim, J. The Effect of Temperature on Chromium Vaporization and Oxide Scale Growth on Interconnect Steels for Solid Oxide Fuel Cells. J. Power Sources 2015, 287, 25-35. [CrossRef]

23. Chevalier, S.; Combemale, L.; Popa, I.; Chandra-Ambhorn, S.; Chandra-Ambhorn, W.; Promdirek, P.; Wongpromrat, P. CHAPTER 6 Development of SOFC Interconnect Stainless Steels. Solid State Phenom. 2020, 300, 135-156. [CrossRef]

24. Froitzheim, J.; Ravash, H.; Larsson, E.; Johansson, L.G.; Svensson, J.E. Investigation of Chromium Volatilization from FeCr Interconnects by Denuder Technique. J. Electrochem. Soc. 2010, 157, B1295. [CrossRef]

25. Ghiara, G.; Piccardo, P.; Bongiorno, V.; Geipei, C.; Spotorno, R. Characterization of Metallic Interconnects Extracted from Solid Oxide Fuel Cell Stacks Operated up to 20,000 h in Real Life Conditions: The Air Side. Energies 2020, 13, 6487. [CrossRef]

26. Dogdibegovic, E.; Wang, R.; Lau, G.Y.; Karimaghaloo, A.; Lee, M.H.; Tucker, M.C. Progress in Durability of MS-SOFCs with Infiltrated Electrodes. J. Power Sources 2019, 437, 226935. [CrossRef]

27. Żurek, J.; Wessel, E.; Niewolak, L.; Schmitz, F.; Kern, T.-U.; Singheiser, L.; Quadakkers, W.J. Anomalous Temperature Dependence of Oxidation Kinetics During Steam Oxidation of Ferritic Steels in the Temperature Range 550-650 ${ }^{\circ}$ C. Corros. Sci. 2004, 46, 2301-2317. [CrossRef]

28. Sánchez, L.; Hierro, M.P.; Perez-Trujillo, F.J. Effect of Chromium Content on the Oxidation Behaviour of Ferritic Steels for Applications in Steam Atmospheres at High Temperatures. Oxid. Met. 2009, 71, 173-186. [CrossRef]

29. Young, D.; Zurek, J.; Singheiser, L.; Quadakkers, W. Temperature Dependence of Oxide Scale Formation on High-Cr Ferritic Steels in $\mathrm{Ar}-\mathrm{H}_{2}-\mathrm{H}_{2} \mathrm{O}$. Corros. Sci. 2011, 53, 2131-2141. [CrossRef]

30. Goebel, C.; Alnegren, P.; Faust, R.; Svensson, J.-E.; Froitzheim, J. The Effect of Pre-Oxidation Parameters on the Corrosion Behavior of AISI 441 in Dual Atmosphere. Int. J. Hydrog. Energy 2018, 43, 14665-14674. [CrossRef]

31. Wang, R.; Pal, U.B.; Gopalan, S.; Basu, S.N. Chromium Poisoning Effects on Performance of (La,Sr) $\mathrm{MnO}_{3}$-Based Cathode in Anode-Supported Solid Oxide Fuel Cells. J. Electrochem. Soc. 2017, 164, F740-F747. [CrossRef]

32. Cheng, F.; Cui, J.; Wang, L.; Li, S.; Sun, J. Performance of Co Ni O Spinel Oxide Coating on AISI 430 Stainless Steel as Interconnect for Intermediate Temperature Solid Oxide Fuel Cell. Int. J. Hydrog. Energy 2017, 42, 12477-12484. [CrossRef]

33. Sickafus, K.E.; Wills, J.M.; Grimes, N.W. Structure of Spinels. J. Am. Ceram. Soc. 1999, 82, 3279-3292. [CrossRef]

34. Biagioni, C.; Pasero, M. The Systematics of the Spinel-Type Minerals: An Overview. Am. Miner. 2014, 99, 1254-1264. [CrossRef]

35. Veronica, D.; Giovanni, B.A.; Danilo, B.; Pier, P.L. Raman Fingerprint of Chromate, Aluminate and Ferrite Spinels. J. Raman Spectro. 2015, 46, 1255-1264.

36. Yung, T.-Y.; Tseng, H.-P.; Yang, P.; Liu, L.-K. The Effects of Thermal Aging on Metallic Interconnects of Solid Oxide Fuel Cells. Mater. Res. Innov. 2013, 17, s129-s135. [CrossRef] 